\title{
Michael Ingham, Johnnie To Kei-Fung’s PTU.
}

\section{Camille Deprez}

\section{(2) OpenEdition}

Journals

Édition électronique

URL : http://journals.openedition.org/chinaperspectives/4880

DOI : 10.4000/chinaperspectives.4880

ISSN : 1996-4617

\section{Éditeur}

Centre d'étude français sur la Chine contemporaine

\section{Édition imprimée}

Date de publication : 1 septembre 2009

ISSN : 2070-3449

\section{Référence électronique}

Camille Deprez, " Michael Ingham, Johnnie To Kei-Fung's PTU. », China Perspectives [En ligne], 2009/3 | 2009, mis en ligne le 16 octobre 2009, consulté le 22 septembre 2020. URL : http://

journals.openedition.org/chinaperspectives/4880 ; DOI : https://doi.org/10.4000/chinaperspectives. 4880

Ce document a été généré automatiquement le 22 septembre 2020.

(c) All rights reserved 


\title{
Michael Ingham, Johnnie To Kei- Fung's PTU.
}

\author{
Camille Deprez
}

Michael Ingham, an associate professor at Hong Kong's Lingnan University, continues the work begun by a series of authors and critics specialising in cinema, Hong Kong, or both, in a collection dedicated to New Hong Kong Cinema and launched by Hong Kong University Press in 2003.

Ingham illuminates his reading of PTU, directed by Johnnie To in 2003, by the light of his own background in theatre studies and literature, as well as his Francophilia, tools that are unusual but which prove useful for penetrating the universe of this feature film and decoding its meaning. In his book, Ingham takes a contrary view of Johnnie To's reputation and the prejudices surrounding PTU with the idea of cultivating his analysis with two main intentions. He sets out not just to re-evaluate the status of Johnnie To as a cinematographic auteur in his own right, and more particularly as a representative of a certain genre cinema, but also to reassess his film PTU, widely underappreciated by the critics, the public, and the industry, but considered by Ingham as one of the most accomplished works of this extraordinary film-maker.

In contrast to other books in the collection, this work does not start with a summary of the film - the issue here undoubtedly lies outside of the minimalist storyline - but defines at the very outset the place occupied by Johnnie To in the Hong Kong cinema landscape, then situates PTU in its historical and aesthetic context. This initial contextualisation is then developed point by point throughout the remainder of the book. Ingham thus underlines the crucial role played by Johnnie To on Hong Kong's cultural scene since the 1980 s as a film-maker, a producer heading up his own Milkyway Image company since 1996, and an active member of the Hong Kong Arts Development Council (HKADC). These three functions have allowed him to mould a section of local film production in his image, inspiring films that are original, commercially viable, and outside of any other Hong Kong artistic movement - or crisis. Ingham inflects the position developed by Stephen Teo, who in his recent work Director in Action, Johnnie To and the Hong Kong Action Film defines To as an "uneven auteur," 
capable of exercising his talent as an auteur within action cinema, while trying his hand at other film genres in a less convincing manner. According to Ingham, To is a genuine cinematographic auteur, as he exerts total control over his productions, the virtuosity of which is expressed in a variety of genres. In this sense, PTU should not be regarded as a simple action film, but rather as film noir coloured by the detective genre in the eclectic tradition of the French films of Jean-Pierre Melville, for whom To proclaims his admiration, as well as of Alfred Hitchcock and Akira Kurosawa.

the police tribe, but also on public security and threats originating outside of Hong Kong's borders. It's true that the film was shot at the time of the sanitary and economic crisis triggered by SARS and reflects the state of mind of the city at that precise moment in its history, its deserted streets abandoned to all-encompassing suspicion. But for Ingham, these similarities remain fortuitous, as To had started shooting his film in 2000 , well before this wave of panic broke over the city. In Ingham's view, the film deconstructs above all the conventions of Hong Kong action cinema, such as the scenes of violence tinged with heroism in the manner of John Woo, in favour of a more complex and ambivalent style fed by anti-heroes and irony.

5 Ingham then dissects the narrative framework of the film, from the opening to the final dénouement. This consists of following a special unit of the police force, the Police Tactical Unit, that is determined to help a sergeant in the crime wing recover his service weapon, which has unfortunately been lost during a brawl, and to do it before the end of their patrol that night. The extreme simplicity of the scenario becomes, in the hands of the author, a propitious opportunity for a theatrical reading of the miseen-scène. This reading underlines, for example, the visual symmetry that is set up in the opening scene between the police officer, the triad gang, and a young, nervous client. The characters, seated at different tables in a busy restaurant, embark on a game of musical chairs, making and breaking up a triangular figure on screen. The reduced number of shooting locations and the pronounced interest in outside scenes shot in the streets furthermore allows a parallel to be drawn with a theatre stage on which the actors position themselves statically, and develop in an extremely calculated manner. But this interpretative framework also highlights Hong Kong's evolution, most particularly the transformation of the working-class districts of the Kowloon peninsula into business districts dedicated to consumerism and big international brands. If To transcends the topographical reality of the city in favour of a stylised aesthetic vision, Ingham constantly swings between the details of the hyper-real, fictional world developed by the director (micro) and the cultural and historical aspects particular to Hong Kong (macro), from human interest stories to triad escapades via local food customs.

6 Ingham casts the passionate gaze of the connoisseur over Hong Kong, PTU, and Johnnie To, an enthusiasm that he communicates effectively to the reader through his personal interests, ranging from literature to theatre and the French language. This last choice is justified without doubt by the inspiration that To finds in the French detective films of the 1960s and 1970s, a passion verified once more in his latest film Vengeance, inspired by Jean-Pierre Melville's Le Cercle Rouge, in which Alain Delon was lined up for the leading role, only to be replaced by another "French" star, Johnny Hallyday.

7 However, the book's thematic, narrative, and aesthetic divisions occasionally fail to do justice to the acuity of the subject, falling into redundancy or a profusion of 
comparisons (PTU may have been compared with too many other films from a variety of cultures and eras, creating a "catalogue" effect). A rigorous structuring of the work around the double theme outlined at the beginning, namely the evaluation of Johnnie To as cinematographic auteur and PTU as a neo-noir film, would undoubtedly have reinforced the consistency of the analysis. This latter aspect, often taken out of context by critics and the general public, is made relevant and valid by Johnnie To himself in the interview transcribed in the annex.

8 Translated by Nick Oates 